\title{
HUBUNGAN STATUS EMOSIONAL DENGAN DERAJAT DISMENORE PADA REMAJA PUTRI DI SMKN 12 LOA BUAH SAMARINDA
}

\author{
${ }^{1}$ Nurun Ni'mah, ${ }^{2}$ Anik Puji Rahayu, ${ }^{3}$ Aries Abiyoga \\ 1,3Program Studi IImu Keperawatan, ITKES Wiyata Husada Samarinda \\ ${ }^{2}$ Program Studi Diploma III Keperawatan, , Fakultas Kedokteran Universitas \\ Mulawarman
}

1Nurunnimah05@gmail.com, 2rahayuanik@gmail.com, 3ariesabiyoga@rocketmail.com

\begin{abstract}
ABSTRAK
Latar Belakang : Dismenore merupakan sensasi menyakitkan, kram di perut bagian bawah yang sering disertai dengan gejala lain, seperti berkeringat, sakit kepala, mual, diare, dan gemetaran, semua terjadi sebelum atau selama menstruasi. Remaja perempuan yang mengalami dismenore dapat mengganggu sosial atau aktivitas fisik karena saat nyeri, penderita cenderung diam bahkan tidak ingin berinteraksi dengan orang lain, justru cenderung lebih emosional. Emosional bagian perwujudan apa yang dirasakan seorang perempuan, reaksi terhadap suatu peristiwa atau situasi tertentu. Status emosional dan dismenore pada perempuan merupakan suatu pengalaman yang sadar dan memberikan pengaruh pada aktivitas tubuh, serta secara psikologis mampu mempengaruhi emosi seorang perempuan. Tujuan : Mengidentifikasi status emosional dan menganalisis hubungan status emosional dengan derajat dismenore pada remaja putri. Metode : Penelitian kuantitatif, jenis penelitian deskriftif analitik dengan desain penelitian cross sectional teknik sampel proportionate stratified random sampling, sampel penelitian ini sebanyak 54 siswi kelas X SMKN 12 Loa Buah Samarinda yang mengalami dismenore Hasil : Variabel Status emosional didapatkan klasifikasi emosi positif $33(61,1 \%)$ dan emosi negatif $21(38,9 \%)$ responden. Variabel Derajat dismenore didapatkan klasifikasi ringan $35(64,8 \%)$, sedang $12(22,2 \%)$, berat $5(9,3 \%)$ dan tidak tertahankan $2(3,7 \%)$. uji yang digunakan Pearson Chi-square didapatkan hasil $P$ value $=0,402$, taraf signifikan ( $\alpha$ ) sebesar 0,05 maka $p>$ dari $\alpha$. Hasil tersebut memiliki arti Ho diterima, tidak ada hubungan antara status emosional dengan derajat dismenore pada remaja putri di SMKN 12 loa buah samarinda. Kesimpulan : Tidak terdapat hubungan antara status emosional dengan derajat dismenore pada remaja di SMKN 12 Loa Buah Samarinda
\end{abstract}

Kata kunci : Derajat dismenore, Remaja putri, Status emosional.

\section{PENDAHULUAN}

Dismenore sensasi menyakitkan, kram di perut bagian bawah yang sering disertai dengan gejala lain, seperti berkeringat, sakit kepala, mual, diare, dan gemetaran, semua terjadi sebelum atau selama menstruasi. Ada 2 jenis dismenore: Dismenore primer mengacu pada nyeri tanpa penyakit pelvis patologis yang jelas dan hampir selalu terjadi pertama kali pada perempuan 20 tahun atau lebih muda setelah siklus ovulasi mereka terbentuk. Dismenore sekunder disebabkan oleh kondisi atau patologi pelvis yang mendasarinya dan 
lebih sering terjadi pada perempuan berusia lebih dari 20 tahun.

Menurut (Latthe, 2006) Angka kejadian dismenorea di dunia cukup tinggi. Di Amerika Serikat pada tahun 2012 angka kejadian dismenorea adalah sebesar 72,9\%. Data lainnya juga menunjukkan bahwa rata-rata di NegaraNegara Eropa kejadian nyeri haid terjadi pada $45-97 \%$ perempuan dengan prevalensi terendah di Bulgaria (8,8\%) dan tertinggi mencapai $94 \%$ di negara Finlandia ${ }^{[1]}$. (Mansur, 2012) di Indonesia, angka kejadian dismenorea sebesar $50 \%$ dari jumlah perempuan yang sedang menstruasi, sementara $10 \%$ diantaranya mengalami gejala dismenorea yang berat sehingga memerlukan istirahat dengan berbaring di tempat tidur dan 1018\% remaja putri tidak dapat mengikuti pelajaran di sekolah dengan alasan menderita dismenorea ${ }^{[2]}$. Menurut Dinas Kesehatan Provinsi Kalimantan Timur Tahun 2018 jumlah kejadian Dismenore terbagi tiga bagian, yang pertama nyeri punggung bawah sebanyak 183 orang (dirawat inap), nyeri perut dan panggul 293 orang ( di rawat inap \& 3355 orang (rawat jalan, dan gangguan haid lainnya 24 orang (di rawat inap \& 465 orang (rawat jalan) (Nia A, 2019).

Dismenore terjadi beberapa jam sebelum atau bersamaan dengan mulai menstruasi dan berlangsung selama 48 hingga 72 jam. Meningkatnya produksi prostaglandin dan pelepasan dari endometrium selama pemicu menstruasi kontraksi rahim yang tidak terkoordinasi dan tidak diatur sehingga menyebabkan rasa sakit. Dismenore memiliki dampak tidak baik pada kehidupan remaja. Menurut (Bernardi, M, 2017) dismenore dapat mengakibatkan aktivitas terganggu, kinerja dan prestasi akademik lebih rendah, mengganggu kualitas tidur, berdampak negatif pada mood, serta menyebabkan kegelisahan dan depresi $^{[3]}$. (Latthe, 2006) menyebutkan beberapa faktor resiko penyebab terjadinya dismenore primer, antara lain yaitu riwayat keluarga, usia menarche dini ( $<12$ tahun), siklus menstruasi yang lebih panjang, Indeks Massa Tubuh (IMT) rendah, status sosial ekonomi dan gaya hidup yang tidak sehat (diet, stres dan merokok $)^{[3]}$. (Hawari 2011) Stres dapat mengganggu kerja sistem endokrin sehingga menyebabkan menstruasi yang tidak teratur dan 
timbulnya rasa nyeri saat menstruasi ${ }^{[3]}$. Menurut (Prawiroharjo, 2010) Keadaan tersebut menyebabkan menurunnya kualitas hidup perempuan, sebagai contoh siswi yang mengalami dismenorea primer tidak dapat berkonsentrasi dalam belajar dan motivasi belajar menurun karena nyeri yang dirasakan ${ }^{[2]}$. Remaja perempuan yang mengalami dismenore dapat mengganggu sosial atau aktivitas fisik karena saat mengalami nyeri, penderita cenderung diam bahkan tidak ingin berinteraksi dengan orang lain, atau justru cenderung lebih emosional ${ }^{[4]}$. Emosional atau ketegangan/gelisahan menimbulkan perasaan yang tidak nyaman dan asing. Dismenore dapat berkaitan dengan faktor penyebab terjadi emosional atau ketegangan saat aktivitas belajar dan pembelajaran juga dapat menurunkan konsentrasi ${ }^{[5]}$. Status emosional dan dismenore pada perempuan merupakan suatu pengalaman yang sadar dan memberikan pengaruh pada aktivitas tubuh dan menghasilkan sensasi organis dan kinetis serta secara psikologis mampu mempengaruhi emosi seorang perempuan $^{[6]}$. Emosional merupakan suatu kompleks keadaan perasaan dengan komponen psikis, soatik, dan perilaku yang berhubungan dengan efek atau mood ${ }^{[7]}$. Perempuan yang menderita dismenore lebih cenderung untuk mengalami gangguan psikologis seperti perubahan mood, depresi, kecemasan dan somatisasi. tersinggung (emosi lebih sensitif) dan lebih memilih tidur. Rata-rata usia yang mengalami hal tersebut adalah 15-16 tahun. Perempuan dengan lama menstruasi 3-7 hari akan berdampak pada emosi yang dirasakan, semakin lama seorang perempuan mengalami mesntruasi, semakin lama pula perubahan yang terjadi termasuk emosional yang dirasakan dalam menghadapi persoalan ${ }^{[10]}$. Dari uraian diatas menunjukkan bahwa banyak perempuan yang mengalami disminore dan membuat mereka mudah emosional yang mengakibatkan derajat dismenore meningkat. Maka perlunya adanya penelitian untuk mengetahui lebih dalam apakah status emosional dapat mempengaruhi derajat dismenore

\section{METODE}

Jenis penelitian ini menggunakan metode kuantitatif, dengan rancangan penelitian Deskriptif Analitik dengan pendekatan Cross Sectional. Populasi dalam penelitian ini adalah semua siswi kelas 10 di SMKN 12 Samarinda Loa Buah, yang berjumlah 62 siswi yang terbagi dari 4 kelas. Sampel pada penelitian ini adalah semua siswi yang terbagi dari 4 kelas menggunakan rumus sampel slovin sebanyak 54. Pengambilan data pada status emosional menggunakan kuesioner yang sudah ada, sedangkan pengambilan data derajat dismenore menggunakan skala NRS (Numeric Rating Scal. Data 


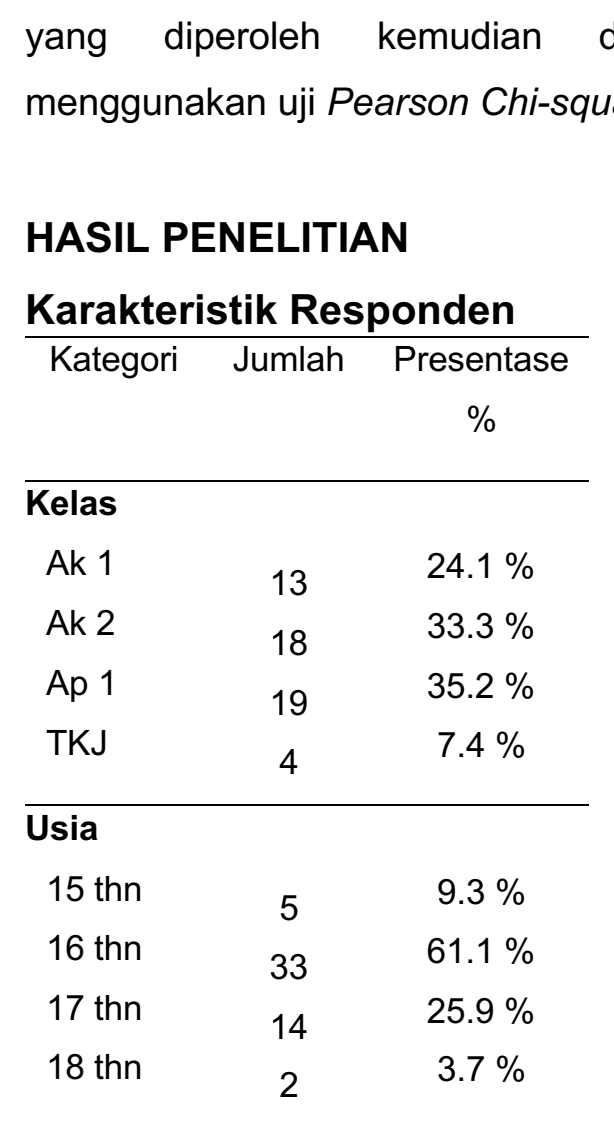

\section{Sumber : Data Primer 2020}

Dari data diperoleh diatas dapat dilihat distribusi data demografi berdasarkan jurusan kelas dan usia yang diperoleh responden terbanyak yang diambil pada kelas AP 1 berjumlah 19 orang dengan presentase $35,2 \%$. Distribusi data demografi berdasarkan usia yang diperoleh responden sebagian besar pada usia 16 tahun dengan rentan usia 15-18 tahun.

Pada kuesioner Status emosional dilakukan uji normalitas data menggunakan Kolmogorov- Smirnov dengan responden 54. Hasil yang didapatkan hasil 0.198 yang memiliki data berdistribusi normal $>0.05$. Data yang berdistribusi normal maka memakai nilai (mena). Peneliti menggunakan nilai mean sebagai cut off point dalam menentukan hasil ukur status emosional Nilai mean yang didapatkan 107. 
Analisis Univariat a. Status emosional Distribusi Frekuensi, Presentase pada status emosional dan derajat dismenore $(n=54)$

Berdasarkan hasil analisis univariat didapat distribusi frekuensi status emosioanal pada remaja putri di SMKN 12 Loa Buah Samarinda . Dari hasil diatas dapat dilihat sebagian besar responden pada kategori emosi positif. Dikarenakan remaja sudah bisa

\begin{tabular}{lcc}
\hline & Frekuensi & $\begin{array}{c}\text { Presentase } \\
\text { (\%) }\end{array}$ \\
Status & & $\%$ \\
emosional & $\mathrm{N} 33$ & 61.1 \\
Emosi Positif & & 38.9 \\
Emosi Negatif & 21 & $\mathbf{1 0 0}$ \\
$\quad$ Total & $\mathbf{5 4}$ & \\
\hline Derajat & & 64.8 \\
Dismenore & 35 & 22.2 \\
$\quad$ Ringan & & 9.3 \\
Sedang & 12 & 3.7 \\
Berat & 5 & $\mathbf{1 0 0}$ \\
$\quad$ Tidak & 2 & \\
tertahankan & & \\
Total & $\mathbf{5 4}$ & \\
\hline
\end{tabular}

Sumber : Data Primer 2020

Analisis variabel status emosional dengan derajat dismenore

\begin{tabular}{lllllll}
\hline Ringan & Sedang & Berat & Tidak & & & Nilai \\
tertahankan & Total & $\%$ & $p$
\end{tabular}

Status Emosional

$$
\begin{aligned}
& \text { Chisquare. } \\
& \text { Skala NRS }
\end{aligned}
$$

dismenore saat menstruasi. Dan dari hasil analisis univariat didapat distribusi frekuensi derajat dismenore pada remaja di SMKN 12 Loa Buah Samarinda. Dari hasil diatas dapat dilihat sebagian besar responden mengalami derajat ringan.

\section{Analisa Bivariat}

Analisa Bivariat dalam penelitian ini menggunkan perhitungan uji Pearson

\begin{tabular}{lcccccccccccc}
\cline { 5 - 11 } & $\mathbf{N}$ & $\mathbf{\%}$ & $\mathbf{N}$ & $\mathbf{\%}$ & $\mathbf{N}$ & $\mathbf{\%}$ & $\mathbf{N}$ & $\mathbf{\%}$ & & & \\
& Emmosi positif & 19 & 76,2 & 9 & 27,3 & 3 & 9,1 & 2 & 6,1 & 33 & 100 & \\
& Emosi negatif & 16 & 57,6 & 3 & 14,3 & 2 & 9,5 & 0 & 0,0 & 21 & 100 & 0,402 \\
Total & 3564,8 & 12 & 22,2 & 5 & 9,3 & 2 & 3,7 & 54 & 100
\end{tabular}


Sumber : Data primer 2020

Hasil dari pengolahan data diatas antara hubungan status emosional dengan derajat dismenore para remaja putri menggunakan uji Pearson Chi-square. didapatkan bahwa $p$ value $=0,402$ dengan taraf signifikan $(\alpha)$ sebesar 0,05 maka $p>$ a. Hasil tersebut memiliki arti Ha ditolak dan Ho diterima, dimana tidak ada hubungan antara status emosional dengan derajat dismenore pada remaja putri di SMKN 12 Loa buah Samarinda.

\section{PEMBAHASAN}

Berdasarkan hasil penelitian yang telah dilakukan oleh penelitian pada 54 responden dengan rentang usia 15-18 tahun, didapatkan hasil berdasarkan karakteristik usia responden yang diperoleh sebagian besar pada usia 16 tahun sebanyak 33 orang dengan jumlah presentase $61,1 \%$.Pada usia 16 tahun. Usia tersebut termasuk dalam kategori remaja dimana sesuai dengan WHO bahwa usia rentang remaja adalah 10-19 tahun. Usia remaja adalah masa dimana terjadi perubahan-perubahan baik secara psikis, maupun biologis. Salah satu masa terjadinya perubahan pada remaja kerab disebut dengan masa pubertas. Pada usia ini remaja sudah mulai mengembangkan kematangan tingkah laku dan belajar mengendalikan emosi ${ }^{[11]}$.

\section{Status Emosional}

Hasil sebaran data pada Status Emosional pada siswi SMKN 12 Loa Buah Samarinda memiliki nilai rata-rata 107,30 , nilai tengah 107 dan Min-Max 82-127, dapat diartikan dari total responden $\mathrm{n}$ (54). Data penelitian jumalah responden 54 orang didapatkan hasil ukur sebagian besar remaja pada kategori emosi positif dibandingkan emosi negatif. jumlah emosi positif dan emosi negatif yang terdapat selisih tidak begitu jauh jumlahnya, jika dilihat berdasarkan aspek dapat mengatur emosi dengan baik emosi positif dan emosi negatif, dapat mengendalikan emosi sadar, mudah dan otomatis, dapat menguasai situasi stres yang menekan akibat dari masalah yang dihadapi. Didapatkan dari kategori dapat mengatur emosi dengan baik emosi positif dan emosi negatif menunjukan pada pertanyaan saya tetap terlihat ceria dihadapan teman-teman meskipun sedang merasakan nyeri perut karena menstruasi menunjukan angka $81 \%$ terlihat bahwa remaja mengungkapkan emosi dengan baik dengan memperlihatkan keceriaan dihadapan teman-temannya agar tidak terjadi sesuatu yang akan menjadi masalah. Pada kategori yang sama pada pertanyaan saya mudah marah ketika saya sedang menstruasi menunjukan angka yang rendah yaitu $51 \%$ perbedaan respon tentang haid mempengaruhi emosi perempuan yang mengalami haid tersebut. Respon emosi pada remaja terhadap menstruasi berbeda-beda, bergantung pada kondisi fisik dan juga tanggapan lingkungan sosialnya ${ }^{[12]}$.

Pada kategori dapat mengendalikan emosi sadar, mudah dan otomatis menunjukan 
pada pertanyaan ketika sedang mengalami nyeri perut, saya memilih tidur daripada berkumpul dengan teman teman menunjukan angka $81 \%$ terlihat bahwa remaja melalukan itu untuk menghindari hal-hal atau keadaan yang tidak di inginkan yang dapat memicu timbulnya emosi. Pada kategori yang sama terdapat pertanyaan yang menunjukan angka yang rendah yaitu $46 \%$ pada pertanyaan saya sulit berkonsentrasi ketika menstruasi hari pertama, terlihat jelas bahwa sebagian besar remaja tidak mengalami kesulitan berkonsentrasi ketika menstruasi hari pertama, seperti kegiatan belajar ataupun eskul dan kegiatan sehari harinya yang membuat mereka fokus akan hal-hal yang akan mereka lakukan.

Pada kategori dapat menguasai situasi stres yang menekan akibat dari masalah yang dihadapinya, menunjukkan pada pertannya saya percaya setiap masalah yang menghampiri pasti ada jalan keluarnya menunjukkan angka 90\% terlihat jelas bahwa banyak remaja yang percaya setiap masalah yang terjadi pasti ada jalan keluarnya, mereka mampu memotivasi diri agar tetap berfikir positif untuk menghindari timbulnya emosi negatif pada remaja. Pada kategori yang sama terdapat pertanyaan yang menunjukkan angka yang rendah yaitu $51 \%$ pada pertanyaan saya kurang maksimal dalam menyelesaikan tugastugas ketika sedang merasakan nyeri perut saat menstruasi, terlihat jelas bahwa sebagian besar remaja masih tetap dapat berfikir dan melakukan sesuatu dengan baik. Setiap orang memberikan reaksi yang berbeda-beda terhadap nyeri haid. Hal ini disebabkan karena nyeri haid tidak hanya dipengaruhi oleh aktivitas tapi dapat disebabkan oleh persepsi setiap individu terhadap nyeri yang bersifat subjektif sehingga dapat mempengaruhi respon nyeri yang bervariasi ${ }^{[13]}$.

Penelitian ini sejalan dengan penelitian (Susanti, Pamela, \& Haryanti, 2018) mengatakan hasil penelitian menunjukkan perkembangan mental emosional remaja sebagian besar pada kategori baik lebih banyak sedangkan pada kategori kurang baik lebih sedikit. Meskipun sebagian besar perkembangan mental emosional dalam kategori baik akan tetapi banyak juga perkembangan mental emosional yang kategori kurang baik dengan selisih yang sedikit.

\section{Derajat Dismenore}

Hasil sebaran data pada derajat dismenore pada remaja putri SMKN 12 Loa Buah Samarinda jumlah responden sebanyak 54 orang didapatkan hasil ukur sebagian besar remaja derajat dismenore pada kategori derajat ringan yang artinya tidak sampai mengganggu aktivitas.

Intensitas nyeri dalam kategori nyeri ringan dapat berupa terasa kram perut bagian bawah, masih dapat ditahan, masih dapat melakukan aktivitas, masih dapat 
berkonsentrasi belajar sebelum dan selama haid.

Menurut analisa peneliti derajat dismenore ringan yang dirasakan para remaja putri ini bisa terjadi karena pada hasil pengisian kuesioner siswi lebih banyak berusia 16 tahun pada usia ini pertumbuhan fisik dan reproduksi sudah mulai berfungsi secara optimal dapat memproduksi sel telur yang tidak dibuahi, rahim yang sudah mulai berkembang dengan baik dan mulai siap mengalami perubahan perubahan sehingga hanya menimbulkan nyeri ringan. Analisis ini sesuai dengan pendapat (Widjanarko 2006 Dismenore, Farmakologi, Misliani, \& Firdaus, 2019) yang menyatakan bahwa alat reproduksi wanita harus berfungsi sebagaimana mestinya, namun bila menarche terjadi pada usia yang lebih awal dari normal (11 sampai 16 tahun) dimana alat reproduksi belum siap untuk mengalami perubahan dan masih terjadi penyempitan pada leher lahir maka akan timbul rasa nyeri yang berlebih ketika menstruasi. Penyebab dismenore ketidakseimbangan hormon progesteron dalam darah sehingga mengakibatkan timbul rasa nyeri Wanita yang mengalami dismenore memproduksi prostaglandin 10 kali lebih banyak dari wanita yang tidak dismenore $^{[14]}$.

Hal ini sejalan dengan penelitian (Wulandari, 2009) menyatakan bahwa sebagian besar responden mengalami dismenore ringan. (Prawirohardjo 1999) mengungkapkan dismenore ringan yang dialami oleh responden dapat di pengaruhi oleh faktor kejiwaan/psikologis ${ }^{[15]}$. Kemungkinan responden sudah memiliki kestabilan emosi sehingga tidak mudah mengalami kecemasan yang dapat memicu timbulnya dismenore. Faktor lainnya yang mempengaruhi ringannya tingkat dismenore yang dialami responden adalah tingginya tingkat pengetahuan yang dimiliki responden.

Hal ini sejalan dengan penelitian (Remedina, 2020) menyatakan bahwa derajat nyeri yang dialami pada siswi SMA Muhammadiyah 1 sebagian besar pada kategori nyeri ringan. Penelitian yang dilakukan Klein dan Litt pada populasi remaja (berusia 12-17 tahun) di Amerika Serikat, melaporkan mengalami dismenore, sebagian besar dari mereka yang di kategori nyeri ringan ${ }^{[14]}$. Menurut Potter dan Perry (2006) nyeri merupakan sesuatu yang kompleks, sehingga banyak faktor yang dapat meningkatkan atau mempengaruhi pengalaman nyeri individu. Tingkat perkembangan akan mempengaruhi proses kognitif dalam persepsi nyeri yang dirasakan dan sejalan dengan pertambahan usia. Semakin meningkat usia maka toleransi terhadap nyeri pun semakin meningkat. 


\section{Hubungan Status Emosional dengan} Derajat Dismenore pada Remaja Putri

Hasil penelitian ini menyebutkan bahwa responden mengalami emosi positif dengan derajat dismenore ringan sebanyak 19 orang $(57,6 \%)$, emosi positif dengan derajat dismenore sedang sebanyak 9 orang $(27,3)$, emosi positif dengan derajat dismenore berat sebanyak 3 orang $(9,1 \%)$, dan emosi positif dengan derajat dismenore tidak tertahankan sebanyak 2 orang $(6,1)$. Responden yang mengalami emosi negatif dengan derajat dismenore ringan sebanyak 16 orang $(76,2 \%)$, emosi negatif dengan derajat dismenore sedang sebanyak 3 orang $(14,3 \%)$, emosi negatif dengan derajat dismenore berat sebanyak 2 orang $(9,5 \%)$.

Diungkapkan oleh (Prawiharjo 1999) dismenore ringan yang dialami oleh responde dapat dipengaruhi oleh faktor kejiwaan/psikologis ${ }^{[15]}$. Kemungkinan responden sudah memiliki kestabilan emosi sehigga tidak mudah mengalami kecemasan yang dapat memicu timbulnya dismenore. Faktor lain yang dapat mempengaruhi ringannya tingkat dismenore yang dialami responden adalah tingginya tingkat pengetahuan yang dimiliki responden tentang menstruasi. Responden yang memiliki tingkat pengetahuan yang tinggi tentang menstruasi tentunya lebih memahami bahwa selama menstruasi kemungkinan akan mengalami dismenore sehingga dapat dilakukan langkah-langkah antisipasi untung meringankan beban dismenore.

Hasil dari pengolahan data antara hubungan status emosional dengan derajat dismenore pada remaja putri di SMKN 12 Loa Buah Samarinda, menggunakan uji Pearson Chi-square didapatkan bahwa $P$ value $=0,402$ dengan taraf signifikan $(\alpha)$ sebesar 0,05 maka $p>$ dari $\alpha$. Tidak ada hubungan antara Status Emosional dengan Derajat Dismenore di SMKN 12 Loa Buah Samarinda. Menurut (Potter dan Perry, 2006) Individu yang sehat secara emosional, biasanya lebih mampu mentoleransi nyeri sedang hingga berat dari pada individu yang memiliki status emosional yang kurang stabil ${ }^{[16]}$. (Muntari 2014) menyimpulkan bahwa nyeri haid cenderung lebih sering dan lebih hebat pada gadis remaja yang mengalami konflik emosional, kegelisahan, ketegangan dan kecemasan hal tersebut menimbulkan perasaan yang tidak nyaman dan asing ${ }^{[16]}$.

Peneliti belum menemukan penelitian lain yang meneliti secara spesifik hubungan status emosional dengan derajat dismenore, tetapi peneliti hanya menemukan penelitian yang hampir sama yaitu penelitian yang tidak sejalan dengan penelitian yang dilakukan oleh (A Rahma, Lanti R.D, \& Sri Hidayat, 2014) menyatakan bahwa menunjukan hasil terdapat ada hubungan antara tingkat stres dengan derajat dismenore pada siswi SMA Negeri 1 Surakarta. (Proverawati dan Misaroh, 
2009 menyebutkan haid dapat disebabkan oleh berbagai faktor, seperti faktor kejiwaan, faktor hormonal, faktor psikis, dan faktor resiko ${ }^{[17]}$. Faktor psikis dan faktor kejiwaan memegang peran besar dalam timbulnya nyeri haid. Faktor psikis, seperti tidak stabilnya emosi atau perasaan seorang wanita dapat memicu timbulnya nyeri haid. Faktor kejiwaan, yaitu apabila seorang wanita tidak mendapat pengetahuan menyeluruh tentang haid atau menstruasi dapat mengakibatkan adanya disminorea.

Hasil penelitian di atas sesuai dengan teori (Wang et al, 2004) yang menyebutkan bahwa pada saat stres terjadi respon neuroendokrin sehingga $\mathrm{CRH}$ akan menstimulasi sekresi ACTH dan akan meningkatkan sekresi kortisol adrenal. Hormon-hormon tersebut menyebabkan sekresi Follicle Stimulating Hormone (FSH) dan Luteinizing Hormone (LH) terhambat sehingga menyebabkan sintesis dan pelepasan progesteron terganggu. Hal ini menunjukkan bahwa stres dapat memiliki efek langsung maupun tidak langsung pada konsentrasi prostaglandin di miometrium $^{[16]}$. Selain itu menurut (Puji 2009) tubuh bereaksi saat mengalami stres. Faktor stres ini dapat menurunkan ketahanan terhadap rasa nyeri sehingga menyebabkan dismenore ${ }^{[16]}$.

Remaja yang belum siap dalam menghadapi nyeri menstruasi akan mengalami kecemasan yang berakibat terjadinya penurunan ambang nyeri dan menyebabkan nyeri menstruasi menjadi sangat berat dengan derajat kronis maupun akut, kecemasan sendiri bisa berupa gangguan fisik seperti: gangguan pencernaan, dismenore, dan bisa juga diakibatkan oleh gejala-gejala lain dari berbagai jenis gangguan emosi ${ }^{[18]}$.

\section{KESIMPULAN}

Berdasarkan hasil penelitian yang dilakukan tentang "Hubungan Status Emosional dengan Derajat Dismenore pad Remaja Putri di SMKN 12 Samarinda Loa Buah ", menunjukan Status emosional dengan derajat dismenore pada remaja menunjukan hasil sebagian besar dari responden remaja pada kategori emosi positif dengan derajat dismenore ringan. Dinyatakan tidak ada hubungan berarti status emosional dengan derajat dismenore pada remaja putri di SMKN 12 Loa buah Samarinda.

\section{DAFTAR PUSTAKA}

Wati Linda Ratna, M. D. (2017). Hubungan Aktifitas Fisik dengan Derajat Dysmenorrhea Primer pada. journal of issues in midwifery, Vol. 1 No. 2, , 1-1

Masruroh, A, \& Fitri, N, 2019. Hubungan Asupan Zat Besi Dan Vitamin E Dengan Kejadian Disminore Pada 
Remaja Putri. Jurnal Kebidanan.

Volume 9 No 12019.

Dwihestie, L. K., (2018). DISMENORE PRIMER PADA REMAJA PUTRI. 024(2014), 2014.

Tristiana A, 2017, Hubungan Aktivitas Fisik

Dengan Kejadian Dismenore Primer Pada Santri Di Pondok Pesantren X Di Kabupaten Bogor. Skripsi Kedoktoran, September 2017.

Lestari, N. M. (2013). PENGARUH DISMENOREA PADA REMAJA.

Seminar Nasional FMIPA UNDIKSHA III, 323-329. Diambil kembali dari

ejournal.undiksha.ac.id/index.php/s emnasmipa/article/download.

Yosep, I., dan Sutini, T. (2014). Buku Ajar Keperawatan Jiwa. Refika Aditama Bandung.

Allo S, T., J.R. (2017, Februari ). Hubungan Mekanisme Koping Dengan Regulasi Emosi Pasa Mahasiswa Semester V Yang Mengalami Dismenore $\mathrm{Di}$ Program IImu Keperawatan Fakultas

Kedokteran Universitas Sam Ratulangi. e-Jornal Keperawatan (e-Kp), 5 No 1

Elisa. (2012). Menstruasi Picu Emosionalitas Remaja Putri. Skripsi, Fakultas Psikologi Universitas Proklamasi 45

\section{Yogyakarta}

Santrock, J. W. (2007). Remaja Edisi 11.

In J. 1. Erlangga : Jakarta. Santrock, John W. 2007. Remaja Edisi 11 Jilid 2. Erlangga : Jakarta.

Siregar Eka, S. (2018). Hubungan Paparan

Pornografi Dengan Perilaku Seksual Remaja Di Sma Prayatna Medan.

Medan.

Febriana, Y. E. (2018). Hubungan

Regulasi Emosi Dengan Nyeri Saat Haid (DISMENORE) Pada Remaja. Fakultas Psikologi

Universitas Islam Negri Sultan Syarif Kasim Riau Pekanbaru.

Juliana, I. (2019). Hubungan Dismenore Dengan Gangguan Siklus Haid Pada Remaja Di Sma N 1 Manado. Jurnal Keperawatan, 7(1), 1-8.

Murwitasari, S. B. (2010). Perbedaan Kepekaan Sensivitas Emosi pada Saat Haid dan Tidak Haid (pp. 3240). pp. 32-40. Yogyakarta

Khairunnisa, \& Maulina, N. (2018). Hubungan Aktivitas Fisik dengan Nyeri Haid (Dismenorea) pada Santriwati Madrasah Aliyah Swasta Ulumuddin Uteunkot Conda Kota Lhokseumawe. Averrous, 3(1), 1020.

Dismenore, P., Farmakologi, C., Misliani, A., \& Firdaus, S. (2019). Jurnal Citra Keperawatan Poltekkes Kemenkes Banjaramasin. 7(1), 23-32. 
Ernawati

(2010).

Terapi relaksasi terhadap nyeri

dismenore pada mahasiswi

Universitas

Muhammadiyah Semarang.

Wulandari Lia (2009).

Hubungan tingkat

kecemasan menghadapi

menstruasi dengan

tingkat dismenore pada

siswi kelas VII di SMP

Muhamadiyah Imogiri. Skripsi

.program studi

kebidanan

Remedina Gipfel (2020). Hubungan

Derajat Disminore

Dengan Tindakan Penanganan

Disminore

Di Sma Muhammadiyah 1

Karanganyar. Maternal Vol. Iv No. 1

- April 2020

Silvanus, Sri Mudayatiningsih, W. R. H. (2017). Hubungan Regulasi Emosi dengan Intensitas Nyeri Dismenore Primer pada Remaja Putri di SMAN 7 Malang. Nursing News, 2(3), 588600.

A Rahma, M., Lanti R.D, Y., \& Sri Hidayat,

R. (2014). Hubungan antara Tingkat Stres dengan Derajat Dismenore pada Siswi SMA Negeri 1

Surakarta. 3(2), 170-180

Rahmadhayanti, E., Afriyani,

R., \& Wulandari, A. (2017).
Pengaruh Kompres Hangat

terhadap

Penurunan Derajat Nyeri Haid pada

Remaja Putri di SMA Karya Ibu

Palembang. Jurnal Kesehatan, $8(3)$,

369.

https://doi.org/10.26630/jk.v8i3.621

Arifa Iklimatul (2019). Hubungan

Kecemasan Dengan Derajat

Dismenore Pada Remaja Putri.

(Studi Di SMP PGRI 1 Perak

Kabupaten Jombang). Skripsi,

Program Studi Si Keperawatan

Sekolah Tinggi IImu Kesehatan

Insan Cendekia Medika Jombang.

Agustus, 2019. 